\title{
Membangun Jaringan Wifi Menggunakan Sistem Operasi Windows Server 2008 pada SMK Negeri 1 Pulau Makian
}

\author{
Hasrin Kasim ${ }^{1}$, Sandi Kamarullah ${ }^{2}$ \\ Program Studi Teknik Komputer \\ Akademi Ilmu Komputer Ternate \\ hasrin_kasim@yahoo.com
}

\begin{abstract}
Abstrak
SMK Negeri 1 Pulau Makian merupakan salah satu Sekolah Menengah Kejuruan yang terdapat pada pulau Makian Provinsi Maluku Utara, yang dalam mengelola dan bertukar datanya antar komputer satu dengan komputer yang lain masih bersifat manual dan sederhana yaitu dengan menggunakan flashdisk sebagai alat alternatif untuk memindahkan file, dikarenakan waktu yang dibutuhkan dalam memindahkan file dari komputer yang satu dengan yang lain sangat lama sehingga dianggap kurang efisien. Penilitian ini bertujuan merancang Wireless Fidelity (Wi-Fi) berbasis Windows Server 2008 Enterprise pada SMK Negeri 1 Pulau Makian, Metode pengumpulan data menggunakan Studi literatur mengenai teori-teori atau konsep mengenai Wireless Fidelity (Wi-Fi) dan Studi Lapangan, melihat secara langsung data sistem yang berjalan yang ada pada SMK Negeri 1 Pulau Makian, dengan dibangunnya jaringan Wifi Menggunakan Sistem Operasi Windows Server 2008 pada SMK Negeri 1 Pulau Makian diharapkan dapat mempermudah proses pengiriman data secara cepat dan efisien
\end{abstract}

\section{Kata kunci: Jaringan, Wi-Fi, Windows Server 2008}

\section{Abstract}

SMK Negeri 1 Makian island this one vocational secondary school located on the makian island of North Maluku province. the managing and exchanging data between computers with other computers that are still manual and simple, that is by using flashdisk as an alternative tool for moving files because of the time needed to move files from one computer to another is very long that are considered less efficient, This research aims to design a Wireless Fidelity (Wi-Fi) in Windows Server 2008 Enterprise-based on SMKN 1 Makian Island Method of data collection using the study of literature concerning the theories or the concept of Wireless Fidelity (Wi-Fi) and Field Studies, see directly the data system that runs on the SMKN 1 Makian island. with the building of a Wifi network Using the Windows Server 2008 on SMKN 1 Makian Island expected to ease the process of sending data quickly and efficiently

\section{Keywords: Network, Wi-Fi, Windows Server 2008}

\section{PENDAHULUAN}

Kemajuan teknologi komputer sebagai pengelolah data dan berkembang semakin cepat. Sejak terjadi penggabungan teknologi komputer dengan teknologi komunikasi. Seiring dengan perkembangan yang menggunakan peralatan-peralatan canggih dalam rangka untuk meningkatkan kinerja kerja, maka semua komponen masyarakat harus mampu menyesuaikandiri dengan kondisi zaman. Apalagi adanya tuntutan yang sangat mendesak baik dari pemerintah maupun masyarakat pada umumnya agar setiap lembaga pemerintah maupun swasta mampu memberikan pelayanan secara efisien. Fasilitas tersebut salah satunya adalah penerapan teknologi di bidang pelayanan seperti dimanfaatkan jaringan Wireless Fidelity (Wi-Fi) untuk 
memperpendek kendala akses data antara gedung yang satu dengan lainya.

Wireless Fidelity (Wi-Fi) merupakan alat komunikasi jaringan yang dibuat untuk memancarkan sinyal gelombang elektromagnetik internet sehingga dapat diakses tanpa menggunakan kabel

SMK Negeri 1 Pulau Makian merupakan salah satu Sekolah Menengah Kejuruan yang terdapat pada pulau Makian Provinsi Maluku Utara yang dalam mengelola dan bertukar datanya antar komputer satu dengan komputer yang lain masih bersifat manual dan sederhana yaitu dengan menggunakan flashdisk sebagai alat alternatif untuk memindahkan file dikarenakan waktu yang dibutuhkan dalam memindahkan file dari komputer yang satu dengan yang lain sangat lama sehingga dianggap kurang efisien, maka diusulkan menggunakan media jaringan Wireless Fidelity (Wi-Fi) agar dapat memudahkan dalam bertukar data secara cepat dan efisien

Dengan menggunakan penerapan Wireless Fidelity (Wi-Fi) akan dapat membantu mencegah masalah yang sebelumnya dalam pengiriman dan lebih cepat dan akurat, seiring terjadinya misin formation antara pembawa informasi dan penerima informasi.

\section{Rumusan Masalah}

Dari uraian diatas dapat dirumuskan permasalahan pada setiap Unit kerja pada sistem berjalan belum memiliki akses data yang memadai (manual) sehingga proses pelayanan terhambat maka dalam penelitian ini penulis menggabungkan sistem dengan merancang jaringan Wireless Fidelity (Wi-Fi) yang berbasis Windows Server 2008 Enterprise pada SMKN 1 Pulau Makean, sehingga mempermudah dalam mengakses data

\section{Tujuan Penelitian}

Penelitian ini mempunyai tujuan, untuk merancang Wireless Fidelity (Wi-Fi) berbasis Windows Server 2008 Enterprise, sekaligus untuk mempermudah Proses pengiriman data melalui Wireless Fidelity (Wi-Fi) pada SMKN 1 Pulau Makian

\section{Manfaat Penelitian}

Secara umum jaringan Wireless Fidelity (Wi-Fi) mempunyai bebrapa manfaat yang lebih di bandingkan dengan komputer yang berdiri sendiri:

1. Diharapkan dengan adanya jaringan Wireless Fidelity (Wi-Fi), mempermudah pengaksesan data atau informasi pada pegawai SMKN 1 Pulau Makian.

2. Diharapkan bagi penulis mampu mengembangkan dan dapat diterapkan ilmu pengetahuan tentang jaringan Wireless Fidelity (Wi-Fi) menggunakan Windows Server 2008 Enterprise.

\section{Tinjauan Pustaka}

Dari pengamatan yang dilakukan oleh penulis, penggunaan jaringan komputer dari peneliti sebelumnya yang dilakukan oleh Rudi Subekti dan Junita Natalia Majid, Perancangan Local Area Network (LAN) BerbasisWireless Pada Akademi Ilmu Komputer (AIKOM) Ternate (2009), perancangan ini menggunakan sistema operasi Windows 2000, Nurdin Umamit dan syafri Wireless Local Area Network (WLAN) Berbasis Windows Server 2003 pada SMA Negeri 8 Ternate, AIKOM (2009).

Perbedaan dari kedua karya ilmiah di atas dengan yang diusulkan dalam penelitian ini adalah penulis akan merancang sebuah sistem jaringan Wireless Fidelity (Wi-Fi) menggunakan 
sistem operasi Windows Server 2008 Enterprise dan akan di rancang pada SMKN 1 Pulau Makean

\section{LANDASAN TEORI}

\section{Pengertian Jaringan}

Jaringan komputer adalah sekelompok komputer otonomi yang saling berhubungan anatara satu dengan lainnya menggunakan protokol komunikasi melalui media komunikasi sehingga dapat saling berbagi informasi, programprogram, penggunaan bersama perangkat keras seperti printer, harddisk, dan sebagainya. Selain itu jaringan komputer bisa di artikan sebagai kumpulan sejumlah terminal komunukasi yang berada diberbagai lokasi yang terdiri dari lebih satu komputer yang saling berhubungan. Manfaat yang didapat dalam membangun jaringan komputer, yaitu :

1. Sharing resources bertujuan agar seluruh program, peralatan atau peripheral lainnya dapat dimanfaatkan oleh setiap orang yang ada pada jaringan komputer tanpa terpengaruh oleh lokasi maupun pengaruh dari pemakai.

2. Media komunikasi jaringan komputer memungkinkan terjadinya komunikasi antar pengguna, baik untuk teleconference maupun untuk mengirim pesan atau informasi yang penting lainnya.

3. Integrasi data jaringan komputer dapat mencegah ketergantungan pada komputer pusat, karena setiap proses data tidak harus dilakukan pada satu komputer saja, melainkan dapat didistribusikan ketempat lainnya. Oleh sebab inilah maka dapat terbentuk data yang terintegrasi yang memudahkan pemakai untuk memeperoleh dan mengolah informasi setiap saat.
4. Pengembangan dan pemeliharaan peralatan dapat dilakukan dengan mudah dan menghemat biaya, karena setiap pembilaan komponen seperti printer, maka tidak tperlu membeli printer sejumlah komputer yang ada tetapi cukup satu buah karena printer itu dapat digunakan secara bersamasama. Jaringan komputer juga memudahkan pemakai dalam merawat harddisk dan peralatan lainya, misalnya untuk memberikan perlindungan terhadap serangan virus maka pemakai cukup memusatkan perhatian pada harddisk yang ada pada komputer pusat.

5. Keamanan data sistem jaringan komputer data memberikan perlindungan terhadap data. Karena pemberian dan pengaturan hak akses kepada para pemakai, serta teknik perlindungan terhadap hardidsk sehingga data mendapatkan perlindungan yang efektif.

6. Sumber daya lebih efisen dan informasi teknik dengan pemakai sumber daya secara bersama-sama, akan mendapatkan hasil yang maksimal dan kualitas yang tinggi. Selain itu data atau informasi yang diakses selalu terbaru, karena setiap ada perubahan yang terjadi dapat segera langsung diketahui oleh setiap pemakai.

\section{Pengertian Sistem jaringan}

Pengertian Sistem Jaringan Komputer adalah sebuah sistem yang terdiri atas komputer, software, dan perangkat yang lainnya yang bekerja bersama-sama untuk mencapai suatu tujuan yang sama. Umumnya,sistem ini terdiri atas banyak layanan atau serviceyang ditunjuk untuk 
melayani pengguna, seperti layanan berbagi berkas, layanan berbagi alat pencetak, DSN (Domain Name System) service, HTTP ( Hypertext Transfer Protocol) Sevice, dan lain sebagainya

\section{Pengertian Wi-Fi}

Menurut Mulyanto (2008: 52) Wi-Fi merupakan merek dagang wireless LAN yang diperkenalkan dan distandarisasi oleh Wi-Fi Alliance. Sedangkan hotspot (wi-fi) yang akan dibahas dalam penelitian ini adalah sarana terkoneksinya jaringan internet tanpa kabel, dengan menggunakan standar wireless LAN, namun demikain dalam menjalankan hotspot diperlukan sarana lain, seperti Notebook/laptop/PDA yang memiliki fasilitas wireless LAN

Menurut Priambodo dan Heriadi (2005), Komunikasi tanpa kabel/nirkabel (wireless) telah menjadi kebutuhan dasar atau gaya hidup baru masyarakat informasi. LAN nirkabel yang lebih dikenal dengan jaringan Wi-Fi menjadi teknologi alternatif dan relatif lebih mudah untuk diimplementasikan dilingkungan kerja seperti laboratorium komputer dan sebagainya. Instalasi perangkat jaringan Wi-Fi lebih fleksibel karena tidak membutuhkan penghubung kabel antar komputer. Tidak seperti halnya Ethernet LAN (local area network)/ jaringan konvensional yang menggunakan jenis kabel koaksial dan kabel UTP (Unshielded Twisted Pair) sebagai media transfer. Komputer dengan Wi-Fi Device dapat saling terhubung yang hanya membutuhkan ruang atau space denga syarat jarak jangkauan dibatasi kekuatan pancaran sinyal radio dari masing-masing komputer.

WiFi atau Wireless Fidelity adalah satu standar Wireless Networking tanpa kabel, hanya dengan komponen yang sesuai dapat terkoneksi ke jaringan. Teknologi Wi-Fi memiliki standar, yang ditetapkan oleh sebuah institusi internasional yang bernama institute of electrical and electronic engeneers (IEEE), yang secara umum sebagai berikut

1. StandarIEEE 802.11a yaitu Wi-Fi dengan frekuensi 5 Ghz yang memiliki kecepatan 54 Mbps dan jangkauan jaringan $300 \mathrm{~m}$

2. Standar IEEE 802.11 b yaitu Wi-Fi dengan frekuensi 2,4 Ghz yang memiliki kecepatan 11 Mbps dan jangkauan jaringan 100m

3. Standar IEEE 802.11g yaitu Wi-Fi dengan frekuensi 2,4 Ghz yang memiliki kecepatan 54 Mbps dan jangkauan jaringan 300m

Teknologi Wi-Fi yang diimplementasikan biasanya adalah standar IEEE 802.11g karena standar tersebut lebih cepat untuk proses transfer data dengan jangkauan jaringan yang lebih jauh sertadukungan vendor (perusahaan pembuat hardware)

\section{Pengertian Windows Server 2008}

Windows Server 2008 adalah nama sistem operasi untuk server dari perusahaan Microsoft. Sistem server ini merupakan pengembangan dari versi sebelumnya yang disebut Windows Server 2003. Pada tanggal 15 Mei 2007, Bill Gates mengatakan pada konferensi WinHEC bahwa Windows Server 2008 adalah nama baru dari Windows Server "Konciiiiii".

Windows Server 2008 mendukung sistem klien dengan Windows Vista, mirip seperti hubungan antara Windows Server 2003 dan Windows XP. Versi Beta 1 dari sistem server ini pertama kali dikenalkan pada tanggal 27 Juli 2005, dan versi Beta 
3-nya sudah diumumkan pada tanggal 25 April 2007 yang lalu. Produk ini rencananya akan dipasarkan pada pertengahan kedua tahun 2007 ini. Windows Server 2008 adalah nama sistem operasi untuk server dari perusahaan Microsoft. Sistem server ini merupakan pengembangan dari versi sebelumnya yang disebut Windows Server 2003. Windows Server 2008 dibangun dari kode yang sama seperti Windows Vista; karenanya Windows Server 2008 memiliki arsitektur dan fungsionalitas yang sama dengannya. Karena Windows Vista, oleh Microsoft, menawarkan kemajuan secara teknis dibandingkan dengan Windows versi sebelumnya, maka hal-hal yang dimiliki oleh Windows Vista juga dimiliki oleh Windows Server 2008. Contohnya adalah network stack yang ditulis lagi dari awal (IPv6, jaringan nirkabel, kecepatan, dan peningkatan keamanan); instalasi yang lebih mudah; diagnosa, pemantauan dan pencatatan yang lebih baik; keamanan yang lebih tangguh seperti BitLocker Drive Encryption, Address Space Layout Randomization (ASLR), Windows Firewall yang lebih baik; teknologi Microsoft .NET Framework 3.0, seperti Windows Communication Foundation, Microsoft Message Queuing (MSMQ), dan Windows Workflow Foundation (WFW), dan juga peningkatan pada sisi kernel.

Windows Server 2008 dibangun dari kode yang sama seperti Windows Vista; karenanya Windows Server 2008 memiliki arsitektur dan fungsionalitas yang sama dengannya. Karena Windows Vista, oleh Microsoft, menawarkan kemajuan secara teknis dibandingkan dengan Windows versi sebelumnya, maka hal-hal yang dimiliki oleh Windows Vista juga dimiliki oleh Windows Server 2008. Contohnya adalah network stack yang ditulis lagi dari awal (IPv6, jaringan nirkabel, kecepatan, dan peningkatan keamanan); instalasi yang lebih mudah; diagnosa, pemantauan dan pencatatan yang lebih baik; keamanan yang lebih tangguh seperti BitLocker Drive Encryption, Address Space Layout Randomization (ASLR), Windows Firewall yang lebih baik; teknologi Microsoft .NET Framework 3.0, seperti Windows Communication Foundation, Microsoft Message Queuing (MSMQ), dan Windows Workflow Foundation (WFW), dan juga peningkatan pada sisi kernel.

Dari sisi perangkat keras, prosesor dan perangkat memori dimodelkan sebagai perangkat keras Plug and Play, sehingga mengizinkan proses hot-plugging terhadap perangkat-perangkat tersebut. Ini berarti, sumber daya sistem dapat dibagi ke dalam partisi-partisi secara dinamis dengan menggunakan fitur Dynamic Hardware Partitioning, di mana setiap partisi memiliki memori, prosesor, I/O secara independen terhadap partisi lainnya.

\section{METODE PENELITIAN}

Metode pengumpulan data yang digunakan dalam penyusunan Tugas Akhir ini adalah:

1. Studi literatur mengenai teori-teori atau konsep yang membahas tentang jaringan lokal dan konsep tentang pengenalan Windows, serta konfigurasi jaringan Wireless Fidelity (Wi-Fi) dengan menggunakan Windows Server 2008 Enterprise.

2. Studi Lapangan, melihat tempat penelitian langsung dilapangan untuk jaringan data sistem yang berjalan.

Teknik pengumpulan data dengan mewawancarai pihak kepala Sekolah SMKN 1 Pulau Makian untuk dukungan dalam penulisan Tugas Akhir 
Kerangka Berpikir

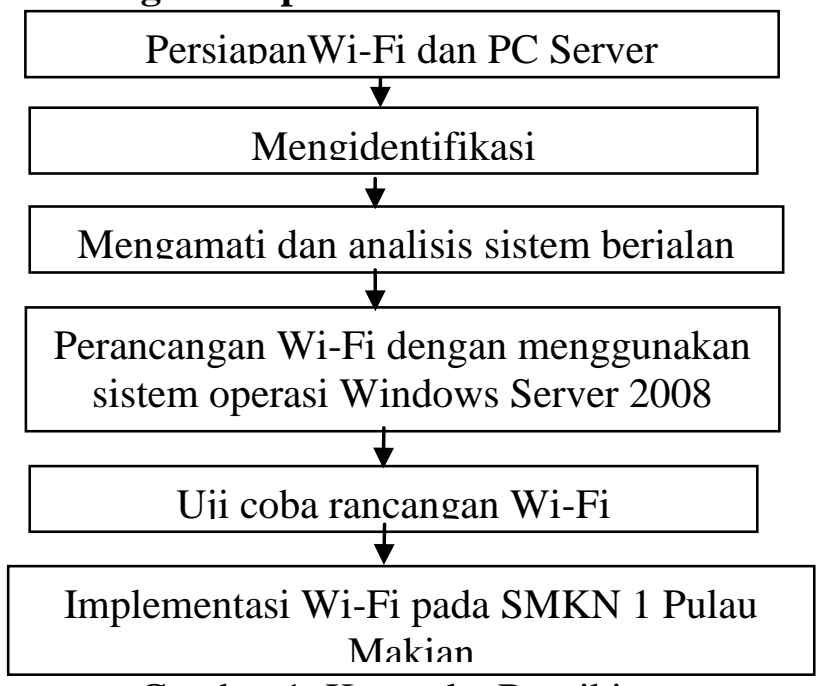

Gambar 1. Kerangka Berpikir

\section{ANALISIS DAN PERANCANGAN}

Dari hasil pengamatan penulis mengenai sistem pertukaran data atau informasi, maka sistem yang digunakan pada SMKN 1 Pulau Makian masih secara manual atau masih menggunakan flashdisk sebagai media pertukaran data/informasi. Dengan demikian pertukaran data atau informasi masih sangat lambat

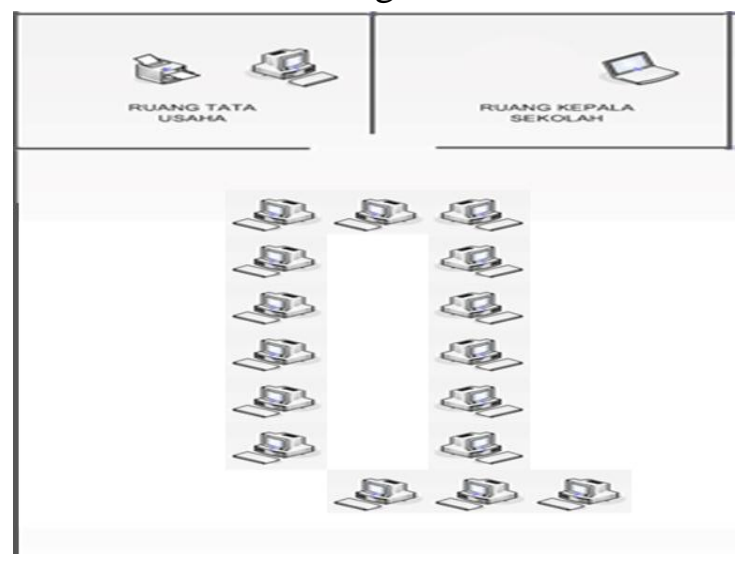

Gambar 2. Analisis Sistem berjalan

Sistem jaringan yang penulis usulkan pada SMKN 1 Pulau Makian ialah bagaiman melakukan pertukaran data/informasi secara otomatis dengan menggunakan Wi-Fi dengan Windows Server 2008 sebagai sistem operasi pada komputer server. Sehingga dapat mempermudah dalam proses pertukaran data/informasi, dan juga dapat memperkenalkan pada para pegawai tentang kelebihan-kelebihan dari sebuah Wi-Fi dan sistem operasi Windows Server 2008, berikut merupakan gambar analisis sistem yang diusulkan

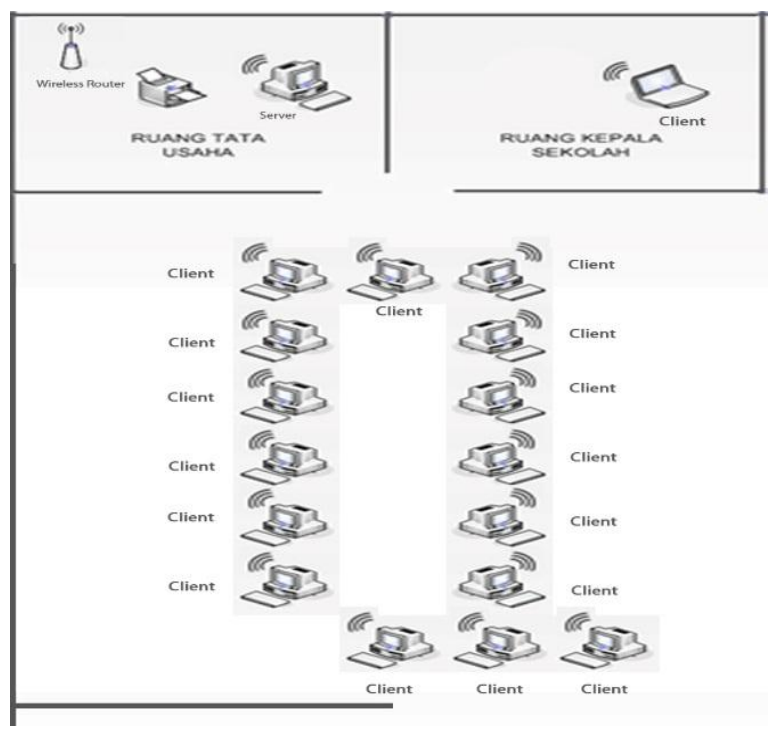

Gambar 3. Analisis Sistem yang diusulkan

\section{Desain Jaringan}

Dari gambar diatas, penulis mencoba melakukan perancangan Wi-Fi dengan menggunakkan Wireless Router sebagai media transmisi. Wireless yang digunakkan adalah TP-LINK yang dihubungkan melalui Wireless, sedangkan jarak antara server dengan client berjarak 5 Meter hingga 10 Meter, ini membuat proses pengiriman data yang dilakukan berjalan dengan baik. Wireless Router diletakkan pada meja yang berukuran 2 Meter, dengan tinggi mencapai 1 Meter. Ruang Tata Usaha di jadikan sebagai ruang server dan ruang Lab Software dan Kepala Sekolah di jadikan sebagai ruang client.

\section{Keamanan pada Wi-Fi}


Teknik yang digunakan untuk mendukung keamanan dalam jaringan WiFi yaitu :

1. Service set Identifier

Service set Identifer (SSID) merupakan 32 karakter unik yang mengidentifikasikan suatu jaringan nirkabel. Pengguna harus mengetahui SSID Wireless Router yang bersangkutan jika melakukan koneksi.

2. Wired Equivalent Privacy (WEP)

WEP digunakan untuk mentransfer data melalui metode enkripsi dan dekripsi , selain itu WEP dapat juga digunakan untuk autentifikasi pengguna melalui protokol WEP.

3. Media Access Control Address (MAC)

Address Filtering

Dalam sebuah jaringan berbasis Ethernet, MAC address merupakan alamat yang unik yangbmemiliki panjang 48 bit yang mengidentifikasikan sebuah komputer, interface dalam sebuah router, atau node lainya dalam suatu jaringan.

\section{IMPLEMENTASI DAN PEMBAHASAN}

Perangkat Lunak yang dibutuhkan

1. Windows Server 2008 Enterprise

2. Windows 7 (client).

3. Driver-driver

\section{Perangkat Keras Server}

1. Sistem operasi yang digunakan Windows 2008 Enterprise untuk jaringan Wi-Fi Spesifikasi server

2. Processor Intel (R) Atom

3. Memory (Ram) 2 GB.

4. Hardisk $500 \mathrm{~Gb}$.

5. Monitor Axioo 11 Inc.

\section{Client/Workstation}

1. Laptop Acer

2. Processor Intel (R) Pentium

3. Memory (Ram) $2 \mathrm{~Gb}$.

4. Hardisk $500 \mathrm{~Gb}$.

\section{Proses Pembuatan Jaringan}

\section{Langkah-langkah setting Access point}

Langkah awal yang di lakukan yaitu buka web browser anda lalu pada addres bar ketikkan http://192.168.1.1 kemudian tekan enter, seperti terlihat pada gambar berikut

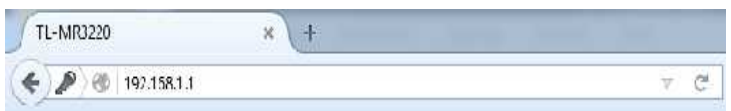

Gambar 4. web browser pada addres

Maka akan muncul jendela user name dan password,pada user name ketik "admin" kemudian pada bagian password ketik juga "admin" kemudian klik OK. Seperti pada gambar berikut

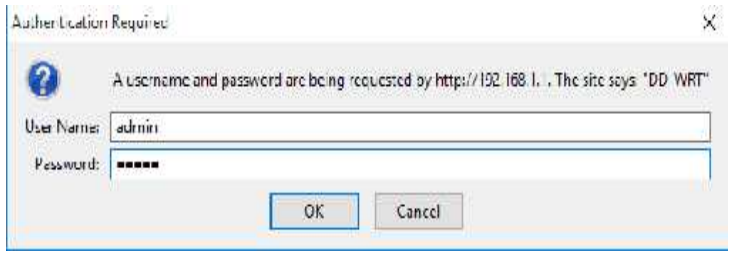

Gambar 5. web User name dan Password

Setelah anda mengklik OK tadi, maka akan tampil jendela konfigurasi Wireless Router Linksys. Klik tab Wireless, di jendela inilah anda akan memasukan nama jaringan wireless yang akan anda gunakan, atau yang sering disebut dengan SSID (Service set indentifier). Seperti pada gambar berikut

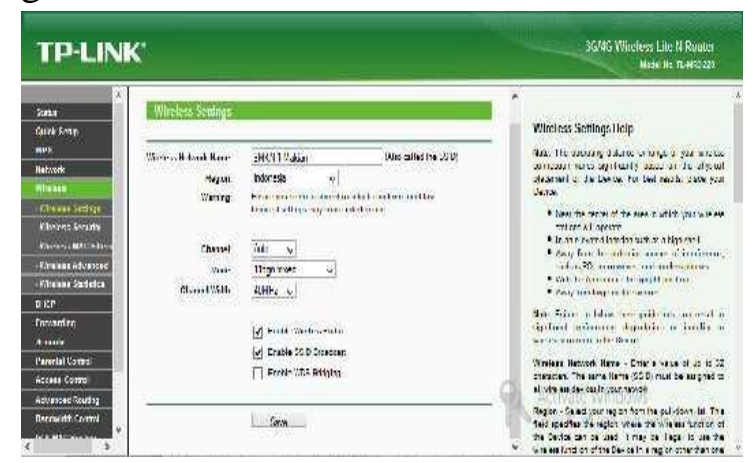


Gambar 6. Jendela konfigurasi Wireless

\section{Router Linksys}

Selanjutnya masuk di wiraless setting, SSID TP-LINK di rubah menjadi SMKN 1 Pulau Makian, dan tekan tombol save kemudian apply settings untuk menyimpan, seperti pada contoh gambar dibawah ini

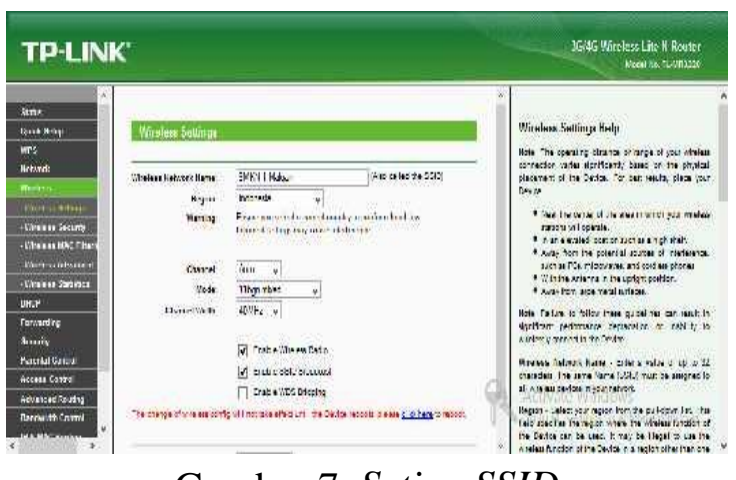

Gambar 7. Seting SSID

\section{Pembahasan Hasil Instalasi}

Dari hasil instalasi pada penelitian yang telah dilakukan pada SMKN 1 Makian dapat ditulis bahwa jaringan Wi-Fi merupakan teknologi yang bertujuan untuk menggantikan jaringan kabel yang menghubungkan terminal komputer dengan jaringan, dengan begitu komputer dapat dipindahkan dengan bebas dan tepat dapat berkomunikasi dalam jaringan dengan kecepatan transmisi oleh IEEE dengan kode 802.11 yang bertujuan untuk menyamakan semua teknologi nirkabel yang digunakan dibidang komputer dan untuk menjamin interoperabilitas antar semua produk-produk yang menggunakan standar ini, standar ini menggunakan $\begin{array}{llll}\text { gelombang } & 2.4 & \mathrm{GHz} & \text { untuk }\end{array}$ mentransmisikan data, standar ini juga masih berdasarkan pada model ISO, hanya berada pada layer data Link dan phisikalnya. Mengingat medium transmisinya berupa udara, teknologi ini membutuhkan tingkat pengamananyang jauh lebih tinggi dari jaringan komputer biasa. Medium transmisi yang berupa udara bebas hanya memungkinkan untuk dua jenis topologi jaringan, yaitu ad-Hoc dan infrastruktur. Meskipun memiliki teknik keamanan yang disebut dengan WEP, namun hasil analisa kemudian menemukan bahwa WEP memiliki kelemahan yang memungkinkan jaringan nirkabel 802.11 b disadap bahkan diserang. Selain itu dapat pula dipelajari lebih lanjut tentang keamanan dari teknologi nirkabel, karena dilihat dari kecenderungan yang ada bahwa dimasa depan hampur semua peralatan elektronik akan terhubung ke jaringan kabel maupun nirkabel, ini akan menimbulkan banyak permasalahan di penggunaan bandwidth dan terutama keamanan, bila aspek keamanan tidak mendapat perhatian yang serius, keselahan yang ada pada WEP dapat terulang lagi, dan mungkin pada saat itu tidak saja jaringan disadap atau diserang tetapi dapat mengakibatkan kerusakan yang lebih parah.

\section{KESIMPULAN}

Setelah dilakukan pembahasan dan uraian-uraian pada bab-bab sebelumnya, maka dapat ditarik beberapa kesimpulan:

1. Dari hasil pengamatan penulis, maka hasil pembuatan dapat mempermudah dalam proses pertukaran data / informasi secara cepat dan efisien serta dapat memperkenalkan pada para pegawai tentang kelebihan-kelebihan dari sebuah Wi-Fi dari sistem operasi Windows 8.

2. Dari hasil penelitian diketahui bahwa Wi-Fi memberikan hasil yang maksimal dalam hal pengolahan data, pertukaran informasi dan terjaminnya keamanan data yang efektif dan efisien. Hal ini sesuai dengan uji coba 
jaringan menggunakan Wireless

Router Mode TP-LINK MR3220

dengan Wireless Data Rate 150Mbps pada frekuensi 2,4 GHz, jangkauannya bisa mencapai jarak $100 \mathrm{~m}$ apa bila tak ada hambatan hambatan.

- Jarak antara Com Server dan Com Client 1 (dari ruang Kepala Sekolah keruang Tata Usaha) dan memeliki kecepatan transfer data 54 Mbps.

- Jarak antara Com Client 2 (dari ruang Kurikulum ke Kepala Sekolah) memiliki kecepatan transfer data $48 \mathrm{Mbps}$

\section{Saran}

Dari hasil kesimpulan dalam penelitian ini dapat disarankan sebagai berikut

1. Diharapkan kepada pihak Sekolah agar proses aktifitas dimana laptop juga diperhatikan, di samping itu, sistem pengoperasian jaringan laptop juga diterapkan

2. Agar dapat memanfaatkan laptop atau jaringan dalam memperlancar pekerjaannya.

\section{DAFTAR PUSTAKA}

Priyambodo, Tri Kuntoro dan Dodi Heriadi. 2005. Jaringan WiFi: Teori dan Implementasi. Yogyakarta: ANDI.

Mulyanta, Edi. 2005. Pengenalan Protokol Jaringan Wireless Komputer. Penerbit ANDI Yogyakarta

Artikel, 2015, Pengertian Wireless Router, Fungsi Wireless Router-Woocara, http://woocara.blogspot.co.id/2015/05/ pengertian-wireless-router.html
Artikel, 2017, Windows Server 2008, Wikipedia Indonesia, ensiklopedia bebas,

https://en.wikipedia.org/wiki/Windows Server_2008

Artikel, 2015, Pengertian ServerKomputer, $h p$, gadget, http://komputerhpgadget.blogspot.co.id /2015/07/pengertian-server.html

Artilkel, 2003, pengertian Wifi-Wikipedia Indonesia, https://id.wikipedia.org/wiki/Wi-Fi

Subekti Rudi dan Majid Junita Natalia 2009, Perancangan Local Area Network (LAN) Berbasis Wireless Pada Akademi Ilmu Komputer (AIKOM) Ternate

Umamit Nurdindan Syafri 2009, Wireless Local Area Network (WLAN) Berbasis Windows Server 2003 SMA Negeri 8 Ternate 